\title{
Foraging habitat and prey taken by least auklets at King Island, Alaska
}

\author{
George L. Hunt, Jr, Nancy M. Harrison* \\ Department of Ecology and Evolutionary Biology, University of California, Irvine, California 92717, USA
}

\begin{abstract}
We examined the foraging distribution and prey use of least auklets Aethia pusilla breeding on King Island in the northern Bering Sea. The location of the King Island colony, in Alaska Coastal Water, but within auklet flight range of the oceanic Anadyr Current and the Anadyr-influenced Bering Shelf Water, provided an opportunity to identify the preferred foraging habitat of the least auklet. Least auklets fed on Neocalanus plumchrus, $N$ cristatus, Eucalanus bungii, and shrimp larvae, all present in Anadyr Current and in Bering Shelf Water. In early June 1984 and July 1985, auklet foraging was concentrated at and just beyond a front ca $30 \mathrm{~km}$ west of King Island, separating Alaska Coastal Water from Bering Shelf Water to the west; large copepods of oceanic origin occurred throughout Bering Shelf Water. Data from 1985 indicated variability in the path of the Anadyr Current; rapid changes also took place in the distribution of the least auklets planktonic prey. In late July 1985 , we documented an intrusion of Anadyr Water from $45 \mathrm{~km}$ to within $25 \mathrm{~km}$ of King Island. Least auklets often overflew the Alaska Coastal Water and foraged in stratified Bering Shelf Water, and in Anadyr Water beyond the front. In 1986. Alaska Coastal Current Water overlaid Bering Shelf Water in much of the area to the west of King Island and a majority of auklets foraged where Bering Shelf Water was closest to the surface. Throughout the study, foraging least auklets were absent from the Alaska Coastal Current near King Island, even though alternative prey, Calanus marshallae, taken elsewhere by breeding least auklets, were present. We conclude that at King Island least auklets sought specific preferred prey in stratified water and near fronts and shifted their foraging over large distances in response to the mobile marine habitat in which their prey were abundant.
\end{abstract}

\section{INTRODUCTION}

Marine birds forage in habitats that are patchy and dynamic. Within habitats, prey patches are ephemeral, with large prey patches generally lasting longer than small patches (Steele 1976, Haury et al. 1978). Additionally, the habitats themselves are mobile, with animal communities carried by currents. Thus, breeding marine birds foraging from a central place not only have to locate patches of prey within a given habitat, but also must respond to movements of the water mass within which the patches of preferred prey occur. We report here the foraging distribution of least auklets Aethia pusilla breeding on King Island, northem Bering Sea, Alaska, in relation to water masses supporting different communities of zooplankton on which these auklets feed.

Factors determining the distribution of foraging sea-

\footnotetext{
- Present address: Nature Conservancy Council, 17 Rubislaw Terrace, Aberdeen AB1 1 XE, Scotland
}

birds in the vicinity of their breeding colonies have long been of interest. Initial emphasis focused on the possibility of density-dependent limitation of seabird numbers due to intraspecific competition for prey near colonies (e.g. Ashmole 1963, Gaston et al. 1983, Furness \& Birkhead 1984, Hunt et al. 1986), and the mechanisms for resource partitioning by which interspecific competition might be reduced (e.g. Ashmole \& Ashmole 1967, Bédard 1969). Cody (1973) suggested that the principal means of resource partitioning in coexisting species of alcids (e.g. auks, puffins) was the use of foraging zones at different distances from their colonies. Bédard (1976) showed that much of Cody's interpretation was flawed. Bédard suggested that the foraging distribution of alcids near their colonies was more likely to be determined by ' . . . the general water circulation and oceanographic conditions...' in the vicinity of the colony. Recently, Kinder et al. (1983) found that frontal systems associated with shoaling of water near the Pribilof Islands (Alaska) supported higher numbers of foraging birds than expected by chance. 
To the extent that preferred prey are restricted to certain water masses, the distribution of the water masses is likely to limit the location of seabird breeding colonies (Hunt et al. in press). In the Bering Sea, Hunt et al. (1981) suggested that the distribution of least auklet colonies was determined by the availability of particular copepod prey. Later, Springer \& Roseneau (1985) showed that the available biomass of $\therefore$ three species of large calanoids, two characteristic of the outer shelf domain and one of the middle shelf domain...' (Iverson et al. 1979, Kinder \& Schumacher 1981) account for the distribution and abundance of breeding least auklets in the eastern Bering Sea. In the northern Bering Sea, the Anadyr Current transports plankton from the waters over the continental shelf break into the shallow Chirikov Basin, where an abundant avifauna depends on this imported food web (Bédard 1969, Springer \& Roseneau 1985, Springer et al. 1987).

In this study, we examined the foraging ecology of least auklets nesting on King Island (see below and Fig. 1). Birds nesting on King Island have access to 2 communities of copepods. Large species, characteristic of the deep oceanic and shelf edge waters, are present both in Bering Shelf Water and in waters transported northward by the Anadyr Current. Smaller copepods, characteristic of the coastal waters, are carried through the Chirikov Basin in the Alaska Coastal Current. Our research focused on whether the auklets would feed on these smaller copepods near King Island, or whether they would overfly the Alaska Coastal Water to forage for the large copepod species present in the Anadyr Current and Berning Shelf Water, as suggested by Bédard (1969) and Drury et al. (1981).

\section{STUDY AREA AND SPECIES}

The Chirikov Basin of the northern Bering Sea is dominated by 2 currents that flow northward through the Bering Strait: the Anadyr Current and the Alaska Coastal Current (Fig. 1). Water in the Anadyr Current originates in the deep Bering Sea, mixes with cold water in the Gulf of Anadys and sweeps northeast, into the shallow Chirikov Basin (50 $\mathrm{m}$ depth), and through the Bering Strait (Coachman et al. 1975). Anadyr Water is cold and highly saline. The Alaska Coastal Current enters the Chirikov Basin from Norton Sound. It is a relatively warm water mass of low salinity derived from the coastal domain water of the southeastern Bering Sea and augmented by the outflow of the Yukon River (Coachman et al. 1975, Kinder \& Schumacher 1981). Sandwiched between these currents in the Chirikov Basin north of St. Lawrence Island is Bering Shelf Water, intermediate in salinity between Anadyr and Alaska Coastal Water and itself a mixture of water from the deep Bering Sea and cold bottom water present on the seasonally frozen, northern Bering Sea shelf (Coachman et al. 1975). The 3 water types present north of St. Lawrence Island differ in density, and the hydrographic structure of the region is marked by fronts where density gradients are steep. The system is

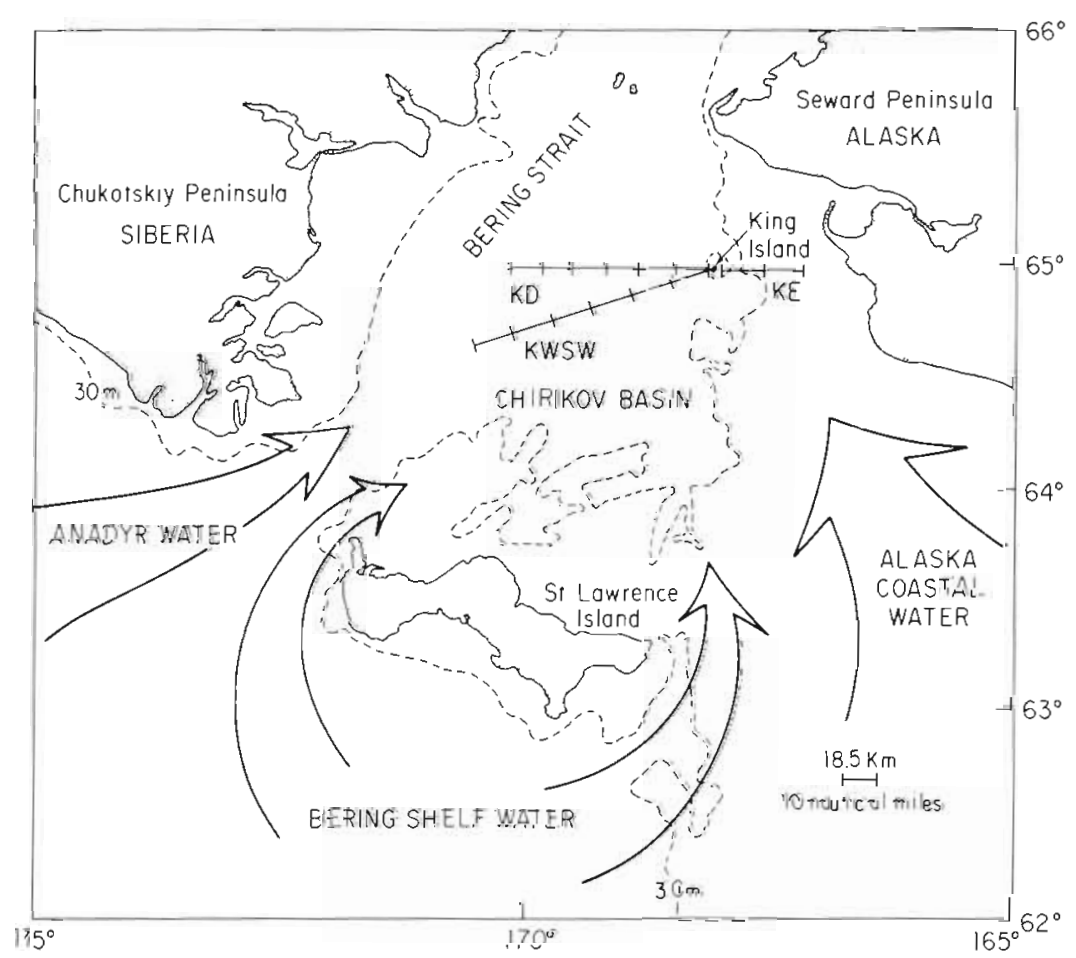

Fig. 1. Study area, showing the relationship between King Island, the Bering Strait, and the major currents entering the Chirikov Ba$\sin$. The transects are $\mathrm{KD}$ from King Island to the United States-Soviet Union Convention Line, KE, to the east of King Island, and KWSW, a line run only on 2 August 1985 , while in transit to St. Lawrence Island 
dynamic with strong fluctuations and an overall average flow into the Bering Strait in summer of about 1 Sverdrup (Coachman et al. 1975, Springer et al. 1989). King Island (Fig. 1) is usually surrounded by Alaska Coastal Water.

The northern Bering Sea is the center of breeding distribution for the least auklet, with colonies supporting in excess of 2 million birds in the region that includes St. Lawrence Island and the islands of the Bering Strait (Sowls et al. 1978). Throughout the Bering Sea, most least auklet colonies are located near the shelf edge, or near oceanic currents originating in deep water (Sowls et al. 1978). Studies during the breeding season indicate that least auklets feed on large calanoid copepods (Bédard 1969, Hunt et al. 1981, Springer \& Roseneau 1985, Roby \& Brink 1986). The large calanoid copepods Neocalanus cristatus (10 mm), $N$. plumchrus $(5 \mathrm{~mm})$, and Eucalanus bungii $(8 \mathrm{~mm})$ generally occur in the oceanic waters of the Bering Sea as well as in currents originating in deep water (Brodskii 1950, Smith \& Vidal 1984, Vidal \& Smith 1986, Springer et al. 1989). Least auklets also take the smaller Calanus marshallae $(4.5 \mathrm{~mm})$ (e.g. at St. Matthew Island; Springer \& Roseneau 1985, Hunt unpubl.), which occurs in shelf water of the middle domain (Meshcheryakova 1970, Smith \& Vidal 1984, Vidal \& Smith 1986). Copepods less than $2 \mathrm{~mm}$ long, such as Acartia spp. and Pseudocalanus spp. dominate inshore (Motoda \& Minoda 1974, Cooney \& Coyle 1982, Smith \& Vidal 1984). Studies in 1985 and 1986 by Springer et al. (1989) showed that the oceanic copepod community dominated by Neocalanus spp. was most abundant in Anadyr Current and Bering Shelf Water and that $C$. marshallae had its greatest abundance in Bering Shelf Water, with smaller numbers present in the Alaska Coastal Current Water.

Based on plumage characteristics, the presence of incubation patches, and gular pouches filled with fresh prey, we determined that the majority of the least auklets observed during this study were adults breeding on King Island. In early July, these birds were incubating eggs, while in late July and early August, they had dependent young. Additionally, particularly in late August, non-breeding birds were present on the water.

\section{METHODS}

To assess the foraging distribution of least auklets with respect to water mass type and zooplankton community composition, we made observations of hydrographic structure, zooplankton assemblages, and foraging auklets. In August 1983 we made a brief visit to the vicinity of King Island and conducted prelimi-
Table 1. Aethia pusilla. Least auklet numbers on short transects radiating from King Island, 1 and 2 July 1984

\begin{tabular}{|lccc|}
\hline $\begin{array}{c}\text { Direction from } \\
\text { King Island }\end{array}$ & Time $(\mathrm{h})$ & $\begin{array}{c}\text { On water } \\
\mathrm{km}^{-1}\end{array}$ & $\begin{array}{c}\text { Flying } \\
\mathrm{km}^{-1}\end{array}$ \\
\hline E & $18: 00-22: 00$ & 0.0 & 0.2 \\
N & $16: 30-17: 20$ & 0.0 & 0.0 \\
N & $17: 45-19: 15$ & 0.1 & 0.1 \\
W & $06: 33-07: 53$ & 0.9 & 3.8 \\
SW & $10: 50-11: 45$ & 0.2 & 3.8 \\
SW & $12: 08-13: 09$ & 0.0 & 0.0 \\
S & $08: 05-09: 10$ & 0.0 & 0.0 \\
S & $09: 22-10: 40$ & 0.1 & 0.5 \\
\hline
\end{tabular}

nary transects to the east, north and west of the island. On 1 and 2 July 1984, we conducted a series of transects radiating out from King Island $30 \mathrm{~km}$ to the east and $18.7 \mathrm{~km}$ to the north, south, southwest and west. Based on the results of these transects (Table 1), and observations of flight patterns of least auklets departing and returning to King Island, we concentrated our observations along a line from $30 \mathrm{~km}$ east of King Island to $80 \mathrm{~km}$ west of the island (Fig. 1). The eastern extent of the line was determined by shoal water near the Seward Peninsula. The westward extent of the line was set by the United States-Soviet Union Convention Line. In 1985, a second line was run for $112 \mathrm{~km}$ westsouthwest of King Island while in transit to St. Lawrence Island, and in 1986 lines $18.5 \mathrm{~km}$ north and $18.5 \mathrm{~km}$ south of and parallel to the line between King Island and the Convention Line were also run. These transects crossed the major north-south oriented oceanographic features of the Chirikov Basin (Fig. 1) and permitted comparison of regions where foraging auklets were expected to be abundant with areas in which auklets were expected to be absent.

Water masses and hydrographic structure were identified using a Neil-Brown CTD (conductivity-temperature-depth) probe. Our practice was to make a CTD cast from the surface to $5 \mathrm{~m}$ from the bottom every $18.5 \mathrm{~km}$ along the transect line, weather permitting. We identified the position of Anadyr, Bering Shelf and Coastal water using salinity profiles. Coastal water was defined as having salinity below $31.8 \mathrm{ppt}$, Bering Shelf Water as between 31.8 and 32.5 ppt, and Anadyr Water as over $32.5 \mathrm{ppt}$ (Coachman 1986). On some runs of the transect (e.g. 26 July 1985) we completed an uninterrupted survey of birds and plankton using high frequency echosounding equipment before returning down the line to take stations. Under this circumstance, no more than $10 \mathrm{~h}$ elapsed between the first bird observations and the last hydrographic station taken.

The zooplankton community was assessed using 2 methods. A single vertical cast with a $1 \mathrm{~m}$ diameter mouth net with $505 \mu \mathrm{m}$ mesh was made at each hydro- 
graphic station. Because multiple casts were not made to assess sampling error, these casts individually are of limited value in determining abundance or biomass of zooplankton. Comparisons of average abundance of zooplankton between water masses were made based on data from casts made over the $3 \mathrm{yr}$ period of the study in Bering Shelf Waters and the Alaska Coastal Current (see Table 3). Identifications of zooplankton samples were completed prior to the description of Neocalanus flemingeri (Miller 1988, Miller \& Clemons 1988 ) and thus our taxon $N$. plumchrus contains an unknown proportion of $N$. flemingeri.

We also include acoustic data for a single transect in 1985, providing information on the vertical and horizontal distribution of zooplankton. We used a Biosonics ${ }^{\text {TM }}$ echo integrator and $200 \mathrm{kHz}$ downwardlooking transducer towed at $2 \mathrm{~m}$ below the surface on a $V$-fin depressor at 6 knots. Data from this source were used to provide a qualitative examination of the dis-

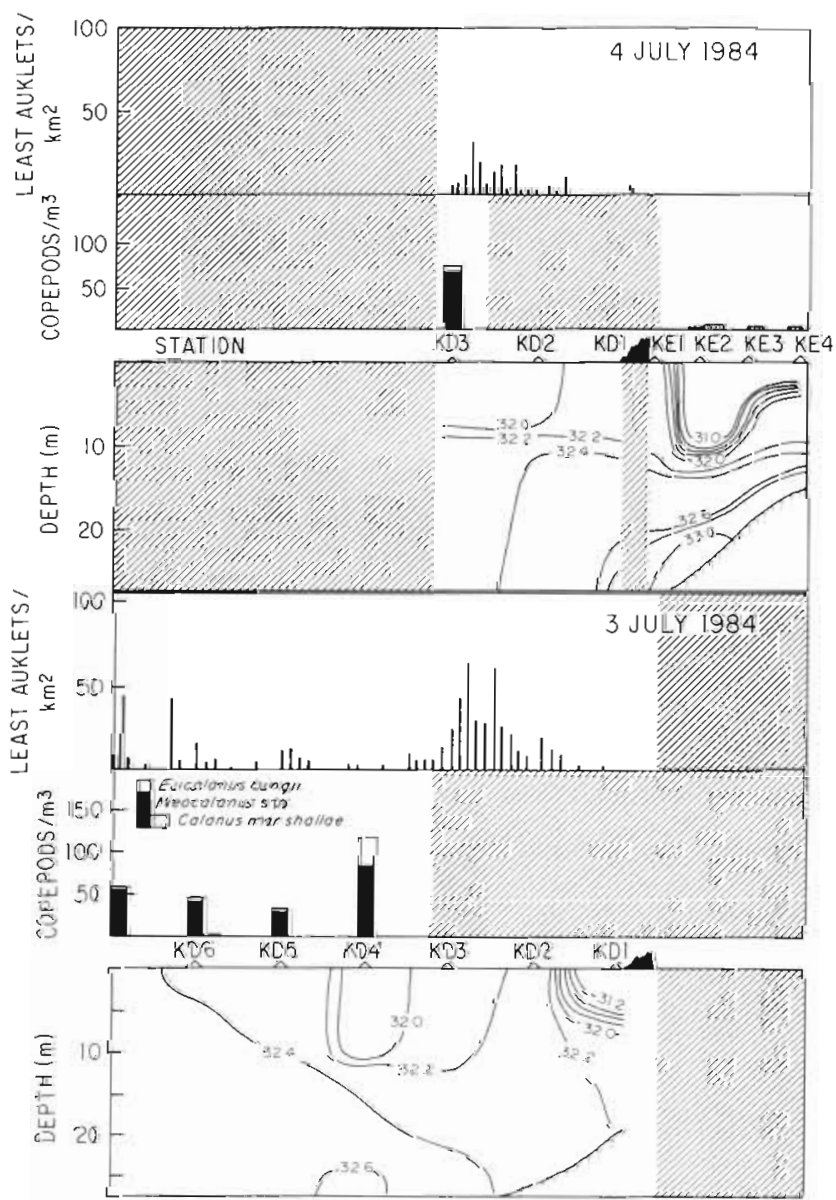

Fig. 2. Salinity profiles, abundances of copepods of various genera and numbers of least auklets per $\mathrm{km}^{2}$ on 3 and 4 July 1984. Hatching represents missing data. Open triangles are station locations. Solid figure to the right of KDI represents King Island. Distance between stations to the west of King Island is $18.5 \mathrm{~km}$; to the east of King Island it is $9.2 \mathrm{~km}$ tribution of zooplankton in the water column relative to where we found birds foraging

Birds were counted from the bridge of the ship (eye height $7.7 \mathrm{~m}$ above the water) in an arc of radius $300 \mathrm{~m}$ from directly ahead of the ship to $90^{\circ}$ off the side of the ship with the best visibility. Data were entered by a second person directly into a microcomputer. The number, species of bird and behavior of each bird or group of birds seen was recorded to the nearest 0.1 min, and position, course, ship's speed and observation conditions were entered every $0.5 \mathrm{~h}$ or when significant changes occurred. Least auklets first observed on the water or surfacing from a dive were presumed to have been foraging where they were observed; with the exception of data in Table 1, only data from birds on the water are reported here.

We systematically collected auklets throughout their foraging distribution along our transects by shooting birds on the sea surface at times when we were not taking data on distribution. We removed stomachs immediately after collection, and searched the auklets sublingual pouches for fresh prey. Samples were preserved in $80 \%$ ethanol for later laboratory analysis. All intact prey in stomachs were tallied as was the percent of the samples in which a given prey occurred. Prey were enumerated and a percent species composition in the prey was calculated. These data provided a second measure of relative importance of prey species.

\section{RESULTS}

In both 1984 and 1985, our transects crossed from the Alaska Coastal Current, east of King Island, to Bering Shelf Water and Anadyr Current Water to the west (Figs. 2 to 6). An important feature of the hydrography near King Island was the transitional zone between the Alaska Coastal Current and the Bering Shelf Water, marked in the CTD records by a strong salinity gradient. This transition was often abrupt. For example, in Fig. 2 the salinity changes from $31.0 \mathrm{ppt}$ to $32.0 \mathrm{ppt}$, as we crossed from Stn KE2 to Stn KE1 on 4 July 1984 , and from $31.2 \mathrm{ppt}$ to $32.3 \mathrm{ppt}$ between Stns KD1 and KD2 on 3 July. The position of fronts in this system frequently shifted over short periods of time (e.g. Fig. 2 and Figs. 3 to 5). From shipboard, when conditions were sufficiently calm as we crossed the front, we could see a sharp convergence with accumulated debris forming a line in the water

We encountered Anadyr Current Water in both 1984 and 1985. In the salinity profiles at the bottom of Figs. 3 to 5, Anadyr Current Water can be seen to varying extents at the western end of the transect as an intrusion of water of $32.5 \mathrm{ppt}$ or greater salinity. In 1984 , the transects remained over a broad mass of Bering Shelf 


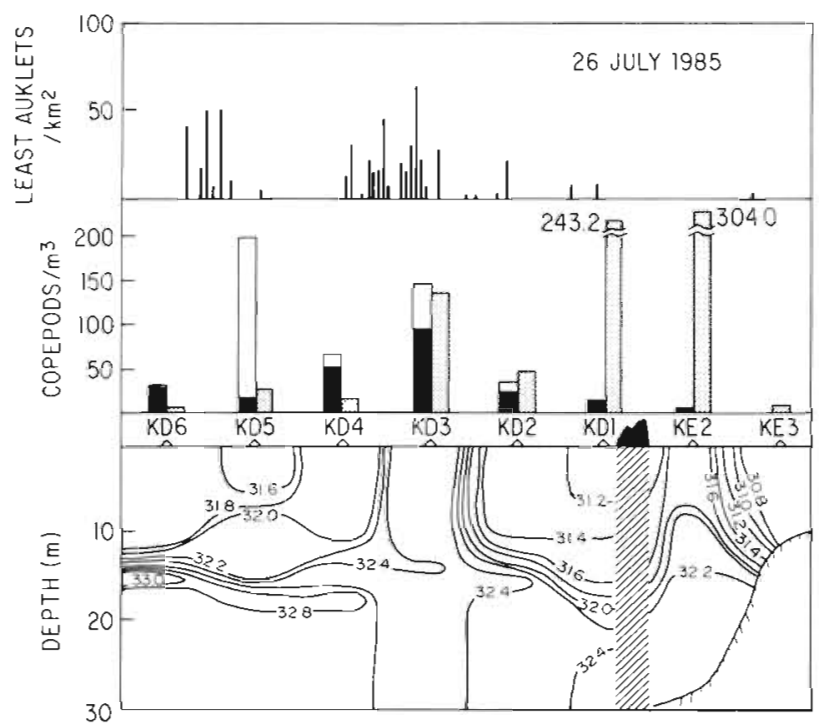

Fig. 3. Salinity profiles, number of copepods of various genera (see key in Fig. 2) and numbers of least auklets per $\mathrm{km}^{2}$, 26 July 1985. Distance between stations is $18.5 \mathrm{~km}$

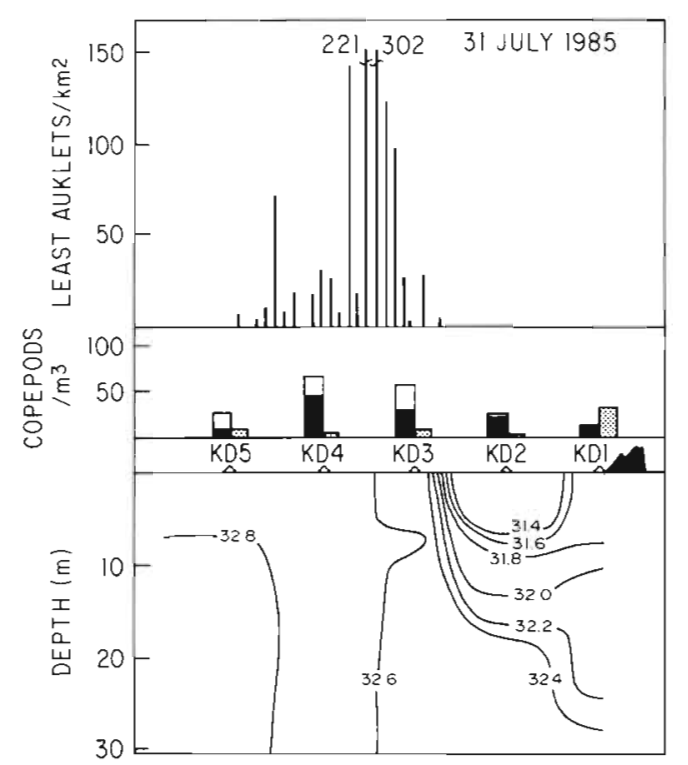

Fig. 4. Salinity profiles, number of copepods of various genera (see key in Fig. 2) and numbers of least auklets per $\mathrm{km}^{2}$, 31 July 1985. Distance between stations is $18.5 \mathrm{~km}$

Water with a small area of high salinity water present near the bottom (Fig. 2).

The intrusion of Anadyr Water in 1985 into the study area completely changed the hydrographic structure beneath the transect within a $7 \mathrm{~d}$ period (Figs. 3 to 5). On 26 July, Anadyr Water was represented by a subsurface intrusion under the halocline (Fig. 3). The system on this date was characterized by a strong halocline, with dense, saline water in a bottom layer and light, relatively fresh water in a shallow surface layer

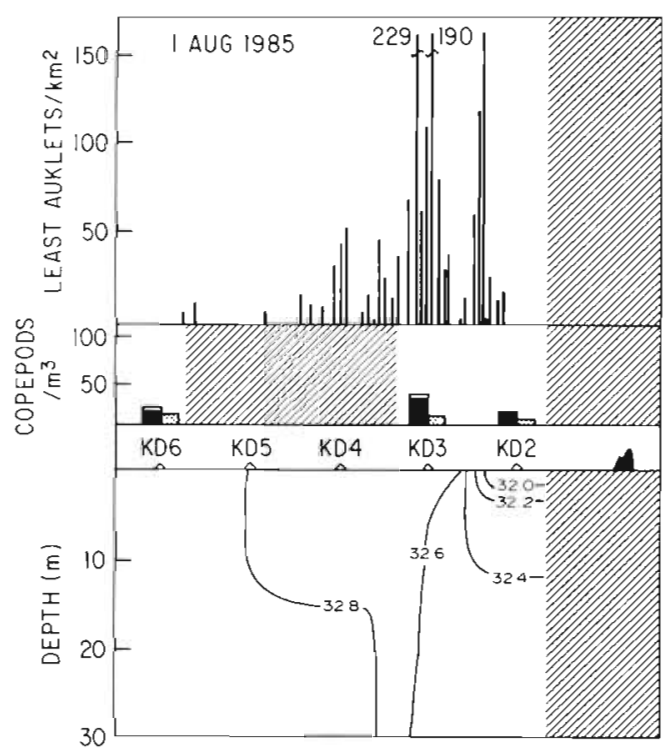

Fig. 5. Salinity profiles, number of copepods of various genera (see key in Fig. 2) and number of least auklets per $\mathrm{km}^{2}$, 1 August 1985. Hatching represents missing data. Distance between stations is $18.5 \mathrm{~km}$

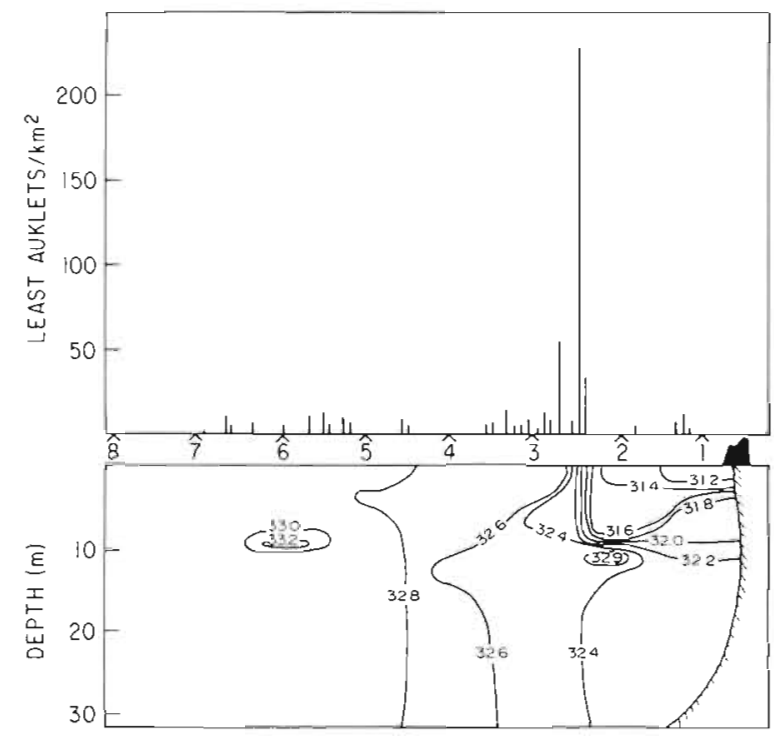

Fig. 6. Salinity profile and numbers of least auklets per $\mathrm{km}^{2}$ on a line WSW from King Island, 2 August 1985. No plankton data are available for this line. Distance between stations is $18.5 \mathrm{~km}$

only $12 \mathrm{~m}$ deep. Between 26 July and 31 July, this vertical hydrographic structure broke down, and was replaced with deep mixing. On 31 July through 2 August (Figs. 4 to 6), the vertical stratification of the water column for the western half of the line was almost completely gone, having been replaced by Anadyr Current Water with virtually complete mixing from the surface to the bottom. Subsequent to the Anadyr intrusions, the stratification evident on 26 July was gone, and in its place was water of intermediate 
Table 2. Abundance (ind. $\mathrm{m}^{-3}$ ) of plankton types sampled by net east and west of a front separating Alaska Coastal Water from Bering Shelf and Anadyr Current Water Early July data from 1984, late July and August data from 1983, 1985 and 1986. Only species commonly used by least auklets are reported

\begin{tabular}{|c|c|c|c|c|c|c|}
\hline & \multicolumn{3}{|c|}{ West of Front } & \multicolumn{3}{|c|}{ East of Front } \\
\hline & Mean & Median & Maximum & Mean & Median & Maximum \\
\hline & \multicolumn{3}{|c|}{ Early July, $N=11$} & \multicolumn{3}{|c|}{ Early July, $N=18$} \\
\hline Neocalanus plumchrus & 44.8 & 38.0 & 104.9 & 0.5 & 0.0 & 2.9 \\
\hline N. cristatus & 6.1 & 1.7 & 39.8 & 0.0 & 0.0 & 0.0 \\
\hline Calanus marshallae & 0.34 & 0.0 & 1.8 & 2.0 & 1.6 & 6.3 \\
\hline Eucalanus bungii & 5.9 & 2.1 & 35.7 & 0.29 & 0.2 & 1.1 \\
\hline Euphausiid larvae & 25.7 & 0.2 & 249.2 & 3.46 & 0.3 & 22.6 \\
\hline Shrimp larvae & 0.41 & 0.2 & 1.3 & 0.13 & 0.0 & 1.7 \\
\hline Crab larvae & 4.7 & 1.8 & 20.6 & 1.9 & 0.8 & 13.4 \\
\hline \multirow[t]{2}{*}{ Parathemisto spp. } & 0.06 & 0.0 & 0.5 & 0.11 & 0.0 & 0.5 \\
\hline & \multicolumn{3}{|c|}{ Late July, August, $N=15$} & \multicolumn{3}{|c|}{ Late July, August, $\mathrm{N}=12$} \\
\hline Neocalanus plumchrus & 32.5 & 28.4 & 88.0 & 5.47 & 1.5 & 21.3 \\
\hline N. cristatus & 1.7 & 1.1 & 5.6 & 0.21 & 0.0 & 1.6 \\
\hline Calanus marshallae & 20.4 & 7.8 & 136.0 & 56.7 & 14.5 & 304.0 \\
\hline Eucalanus bungui & 22.2 & 1.4 & 184.0 & 1.6 & 0.0 & 13.1 \\
\hline Euphausid larvae & 131.1 & 38.4 & 614.0 & 97.9 & 5.8 & 593.0 \\
\hline Shrimp larvae & 0.27 & 0.1 & 1.0 & 0.98 & 0.0 & 9.1 \\
\hline Crab larvae & 3.4 & 1.2 & 20.6 & 1.2 & 0.7 & 4.5 \\
\hline Parathemisto spp. & 0.26 & 0.1 & 1.4 & 0.31 & 0.0 & 0.9 \\
\hline
\end{tabular}

properties ( 32.0 to $32.5 \mathrm{ppt}$ ) as part of a continuous steep gradient from Coastal Water to the oceanic Anadyr Current. Thus rapid changes occurred in both horizontal (the front) and vertical hydrographic structure.

The composition of the copepod community and relative abundance of large zooplankton changed with water mass (Table 2). The Alaska Coastal Current was dominated by one copepod species, Calanus marshallae, and species of planktonic euphausiid and decapod larvae. Bering Shelf and Anadyr Current Water supported large populations of Neocalanus plumchrus, Eucalanus bungii, C. marshallae (in late July), and larval euphausiids and smaller numbers of $N$. cristatus. The difference in the spatial distributions of these 2 copepod communities is best seen in Figs. 2 and 3 . which include the most complete coverage of the transect line in 1984 and 1985. In early July 1984, the line was covered in 2 segments and zooplankton sampling was disrupted by bad weather. Neocalanus spp. were abundant in the Bering Shelf Water and were virtually absent from the Alaska Coastal Current, where small numbers of C. marshallae dominated. In late July 1985, C. marshallae were far more abundant, but primarily occurred in the Alaska Coastal Current and in the frontal zone west of King Island. Neocalanus spp. and E. bungii were relatively scarce in the Alaska Coastal Current, though apparently more abundant there than in 1984; they were most abundant in the Bering Shelf Water (Figs. 3 to 5). Data from 1985 support the conten- tion that the frontal area between Alaska Coastal Water and Bering Shelf Water was an area of transition between the Coastal and Shelf zooplankton communities. For instance, in 1985, Stn KD3 on 26 July (Fig. 3) was centered in the front. The plankton sample at Stn KD3 had an unusually high diversity of zooplankton species including copepods typical of both the shelf and the coastal communities.

Food samples collected from adult least auklets in Bering Shelf Water were dominated by Neocalanus plumchrus, N. cristatus and Eucalanus bungii (Table 3). Few or no Calanus marshallae were found in these birds, despite the abundance of $C$. marshallae in the water column in 1985 (Table 3, Fig. 3). C. marshallae is apparently not a preferred prey when Neocalanus species are present. No least auklets were collected with food east of King Island, because we encountered virtually no foraging least auklets there. More extensive collections of least auklet diet data were obtained in 1984 to 1986 in Bering Shelf Waters north of St. Lawrence Island (Hunt et al. in press). In total, 111 food samples were obtained from the Chirikov Basin, when the collections from near King Island, from near St. Lawrence Island and from 28 regurgitations on a colony near Savoonga, St. Lawrence Island, are combined. Least auklets during our studies were all feeding in the same marine community based on observations of foraging distribution and by the dominance of the same prey throughout sites and years.

During 1984 and 1985, least auklets were consist- 
Table 3. Aethia pusilla. Prey use by least auklets. Sample size in parentheses

\begin{tabular}{|c|c|c|c|c|}
\hline \multirow[t]{2}{*}{ Prey taxon } & \multicolumn{2}{|c|}{1984} & \multicolumn{2}{|c|}{1985} \\
\hline & $\begin{array}{c}\text { Proportion of } \\
\text { samples in which } \\
\text { prey occurred (6) }\end{array}$ & $\%$ Intact prey (37) & $\begin{array}{c}\text { Proportion of } \\
\text { samples in which } \\
\text { prey occurred (15) }\end{array}$ & $\%$ Intact prey (435) \\
\hline \multicolumn{5}{|l|}{ COPEPODS } \\
\hline Neocalanus (all) & 0.83 & & 0.87 & \\
\hline Neocalanus plumchrus & 0.67 & 89 & 0.73 & 47 \\
\hline N. cristatus & & & 0.40 & 8 \\
\hline C. marshallae & & & 0.07 & 0.5 \\
\hline Eucalanus bungii & 0.17 & 11 & 0.20 & \\
\hline Pseudocalanus elongatus & & & 0.07 & \\
\hline Unidentified Neocalanus & 0.33 & & & \\
\hline \multicolumn{5}{|l|}{ OTHER } \\
\hline Pandalidae larvae & & & 0.33 & 34 \\
\hline Brachyura larvae (megalops) & & & 0.20 & 4 \\
\hline Byblis & & & 0.07 & 0.5 \\
\hline Unidentified amphipod & 0.17 & & & \\
\hline Thysanoessa & & & 0.07 & \\
\hline Unidentified Crustacea & 0.17 & & 0.07 & \\
\hline Unidentified fish & & & 0.07 & \\
\hline
\end{tabular}

Table 4. Aethia pusilla. Comparison of numbers of least auklets on the water on Alaska Coastal Water, at the front and on Bering Shelf Water $\leq 18.5 \mathrm{~km}$ west of the front, and $\geq 18.5 \mathrm{~km}$ west of the front on Bering Shelf and/or Anadyr Current Water. N: number of $18.5 \mathrm{~km}$ interstation segments surveyed in 1984 and 1985

\begin{tabular}{|c|c|c|c|}
\hline & Coastal $^{\mathrm{a}}$ & Front/near Front & West of Front \\
\hline $\mathrm{N}$ & 16 & 13 & 13 \\
\hline Mean $\pm S D$ & $3.1 \pm 4.5$ & $132.3 \pm 137.2$ & $26.0 \pm 21.7$ \\
\hline Median & 1 & 85 & 22 \\
\hline Maximum & 15 & 482 & 70 \\
\hline${ }^{a}$ Coastal vs Front/near Front & Mann-Whitney U test & $\mathrm{U}=1, \quad \mathrm{p}<0.001$ & \\
\hline Coastal vs West of Front & Mann-Whitney U test & $U=18, p<0.001$ & \\
\hline
\end{tabular}

ently present in significantly larger numbers at and immediately to the west of the frontal zone between Bering Shelf Water and the Alaska Coastal Current than they were in the Alaska Coastal Current (Table 4, Figs. 2 to 6). We located concentrations of auklets at and to the west of the front at various times from 09:00 until 19:00 h, the daylight hours when auklets were away from their colonies.

In 1984 and 1985, the region in which auklets aggregated on the water was the first area to the west of King Island where the Neocalanus community was regularly present, and the biomass of these copepods was often large. However, based on our limited sampling of zooplankton, there is no evidence of a correlation between the number of auklets seen and the amount of copepods in our tows. As the Anadyr Water intruded from the west, the auklets became increasingly restricted to the area of the front (Figs. 3 to 5). On 1 August 1985, an acoustic survey revealed more plankton biomass in the water immediately to the west of Stn KD2 and more biomass near the surface west of Stn KD2, than for any other area of the survey (Fig. 7). This area of enhanced biomass was in a frontal zone between Anadyr Current Water and Alaska Coastal Current Water (Fig. 5).

Limited observations in 1986 showed a different situation from that encountered in 1984 and 1985 (e.g. Fig. 8). In 1986, Alaska Coastal Water was widespread to the west of King Island. Patches of Bering Shelf Water were encountered, but were overlaid by Alaska Coastal Water (see Springer et al. 1989 for similar hydrographic profiles in July and late August 1986). A surface front was present, but it separated a lens of fresh water at the surface to the west from somewhat saltier water to the east. Auklets were concentrated to the east of this front, above Bering Shelf Water (Fig. 8). We were unsuccessful at collecting food samples from auklets in 1986 . 


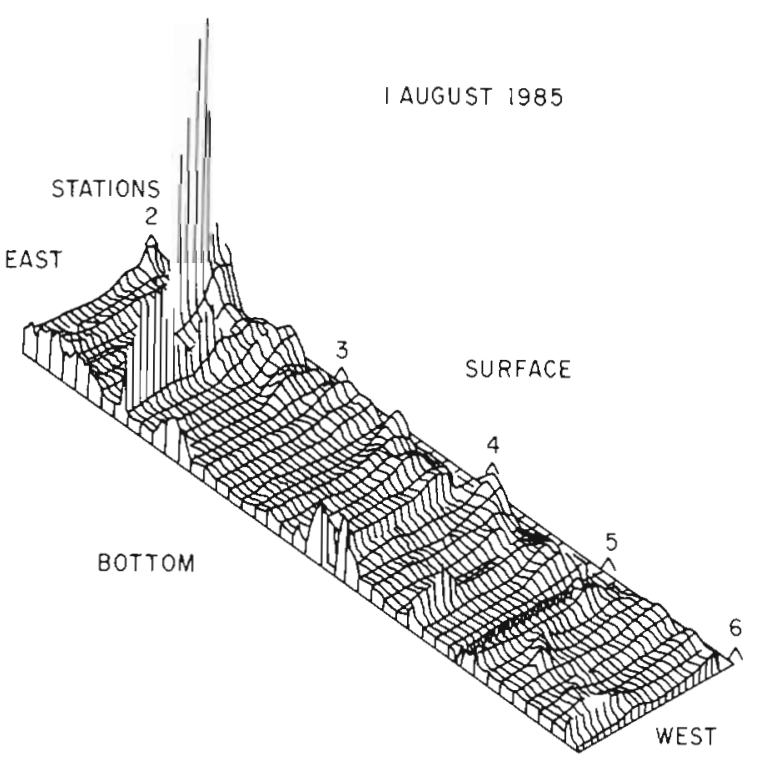

Fig. 7. Distribution of acoustically determined biomass in the water column, 1 August 1985, between Stns KD2 and KD6. Note the peak in biomass near the surface between Strns KD2 and KD3, which coincided with both a peak in auklet numbers and a steep salinity gradient depicted in Fig. 5. Distance between stations is $18.5 \mathrm{~km}$

\section{DISCUSSION}

Our results show that least auklets breeding on King Island often overfly Alaska Coastal Water, containing a prey species (Calanus marshallae) taken elsewhere in the auklets' breeding range (Springer \& Roseneau 1985), to forage on large species of copepods in Bering Shelf and Anadyr Current Water. The front separating
Alaska Coastal Water and Bering Shelf Water is both a barrier to the eastward dispersal of the oceanic copepod community (Springer et al. 1989) and the eastward boundary of the area in which foraging least auklets are common.

Several studies have demonstrated that the foraging distribution of marine birds depends on physical features in the marine environment which influence the availability of prey at scales of 1 to $100 \mathrm{~km}$ (see reviews by Hunt \& Schneider 1987 and Hunt in press). For the southeastern Bering Sea, trophic pathways to birds varied between hydrographic domains (Schneider et al. 1986), but consistent aggregations of birds near the frontal boundaries of these domains were not found (Schneider et al. 1987). No previous studies have shown seabirds avoiding a habitat containing a suitable prey taken elsewhere to forage in a more distant habitat containing an alternative, apparently preferred prey. A similar pattern, but apparently driven by a different mechanism, was found by Briggs et al. (1988) who observed common murres Uria aalge overflying clear water containing their prey to forage on the same prey in murkier water, where prey were presumed to be less able to avoid the predator.

The position of the transition between Alaska Coastal Water and Bering Shelf Water was an important feature of the local hydrography in the Chirikov Basin, determining the location and extent of auklet foraging habitat in 1984 and 1985 . Our analyses of the hydrographic structure of the region and the distribution of plankton communities in both 1984 and 1985 are similar to those found by Springer et al. (1989) during those years. The front separating the Alaska Coastal Water and Bering Shelf Water was not only a transition
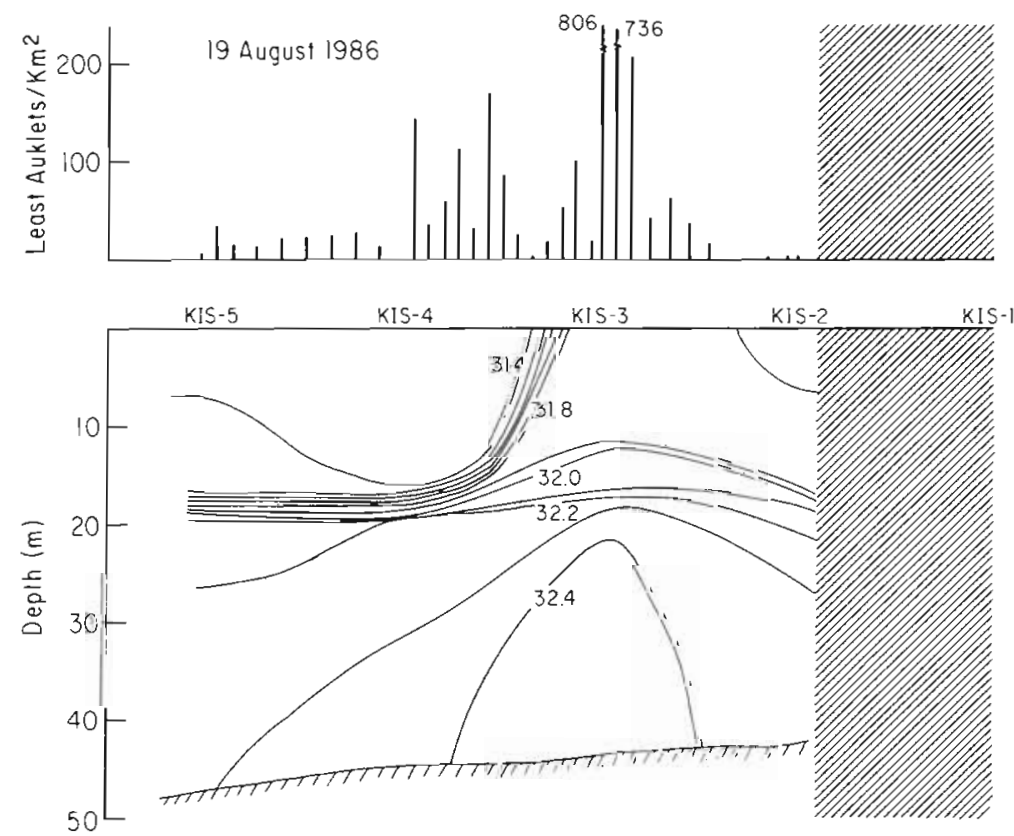

Fig. 8. Salinity profile and numbers of least auklets per $\mathrm{km}^{2}$ on a line running east-west $18.7 \mathrm{~km}$ south of the KD line, 19 August 1986. No plankton data are available for this line. Distance between stations is $18.5 \mathrm{~km}$ 
between the 2 copepod communities, it was also an area of enhanced auklet foraging activity. This aggregation of foraging auklets may have resulted strictly from geographic relationships; the frontal area was the first place on the outward journey from the colony where the birds encountered the large Neocalanus copepods. The front also may have been an area of enhanced prey availability. Circulations within the front may occur, thereby concentrating prey near the surface. The ontogenetic development of the Neocalanus community occurs in deep water south of St. Lawrence Is, in early spring (Cooney \& Coyle 1982 Vidal \& Smith 1986, Miller \& Clemons 1988), hence the front was not a zone of high copepod production, but instead a zone of high accumulation of animals carried by strong currents. In 1986, when a surface front between the coastal water and the Bering Shelf Water was not found, auklets concentrated in an area where the Bering Shelf Water was closest to the surface.

We do not know how the auklets locate either their foraging habitat or patches of prey within it. The birds fly out from their colonies in the early morning, settle on the water to forage, and after completing 1 or 2 round trips in a day, most return to the colony at night. On occasion, the front between the Alaska Coastal Current and the Bering Shelf Water was visible from the ship; from the air birds should see it readily. Additionally, at least late in the season, non-breeding auklets visit the colony and then moult nearby on the water, during which time they are flightless (Hunt et al. in press). If these flightless, molting birds track patches of prey, they may provide commuting birds with valuable clues about favorable foraging areas. Data from near St. Lawrence Island suggest that molting birds concentrate in particularly rich foraging areas (Hunt et al. in press, Hunt unpubl.). Cuing on molting birds would not work early in the breeding season before moulting, non-breeding birds are present.

Finally, we consider why least auklets ignored the Calanus marshallae in the Alaska Coastal Current near King Island, and flew $25 \mathrm{~km}$ or more to the west to forage on the oceanic copepods, Neocalanus cristatus, $N$. plumchrus and Eucalanus bungii. Springer \& Roseneau (1985) have summarized dietary data from a number of least auklets colonies, and have shown that the proportion of $C$. marshallae in their diet shifts among colonies and years. They suggest that such shifts reflect differences in the available biomass of the various plankton species. We and Springer et al. (1989) found that $C$. marshallae was at least occasionally abundant in the Alaska Coastal Current, and it seems unlikely that a lack of prey was the only reason that the least auklets commuted to Bering Shelf Water to forage. Two possible additional reasons for seeking the oceanic copepods are: (1) N. cristatus, E. bungii, and
N. plumchrus are larger than C. marshallae (10.0,8.0, 5.0 and $4.5 \mathrm{~mm}$ respectively) and are therefore potentially easier and more profitable to catch underwater. The similarity in lengths of $N$. plumchrus and $C$. marshallae is deceptive $-C$. marshallae is a much smaller, slighter copepod that stores less lipid (S. Smith pers. comm.). (2) $N$. cristatus is known to form dense nearsurface layers (Barroclough et al. 1969), and our records show concentrations of biomass near the halocline. Thus, in the stratified Bering Shelf Water, it is possible that Neocalanus aggregated along the halocline. We suggest that the larger size, their greater lipid content, and the possibility that they aggregate at haloclines and in frontal zones are all features that would make Neocalanus spp. profitable prey. Their abundance in the stratified Bering Shelf Water should make that an attractive foraging habitat to a bird pursuit-diving for very small prey items.

Acknowledgements. We thank Z. Eppley, K. Coyle, B. Obst, and $\mathrm{C}$. Williams for help with the field observations and collecting for this research. The captain, crew and marine technicians, S. Ellis and D. Boiseau of the RV 'Alpha Helix', were most helpful. Without their cooperation and efforts on our behalf the work would not have been possible. K. Briggs, A. Burger, T Kinder, B. Obst, J. Rice, S. Sealy and S. Smith provided helpful comments on an earlier draft of the manuscript. The research was supported, in part, by NSF Grant DPP-8308232

\section{LITERATURE CITED}

Ashmole, N. P. (1963). The regulation of numbers of tropical oceanic seabirds. Ibis $103 \mathrm{~b}: 458-473$

Ashmole, N. P., Ashmole, M. J. (1967). Comparative feeding ecology of seabirds of a tropical oceanic island. Peabody Mus. nat. Hist. Yale Univ. Bull. 24: 1-131

Barroclough, W. E., Lebrasseur, R. J., Kennedy, O. D. (1969) Shallow scattering layer in the subarctic Pacific Ocean detection by high-frequency echosounder. Science 166 : $611-613$

Bédard, J. (1969). Feeding of the least, crested, and parakeet auklets around St. Lawrence Island, Alaska. Can. J. Zool. 47: $1025-1050$

Bédard, J. (1976). Coexistence, coevolution and convergent evolution in seabird communities: a comment. Ecology 57 : $177-184$

Briggs, K. T., Ainley, D. G., Spear, L. B., Adams, P. B., Smith, S. E. (1988). Feeding of two alcids at central California upwellings. In: Oulette, H. (ed.) Proc. XIX International Ornithological Congress, Ottawa, 1986. Univ. of Ottawa Press, Ottawa, p. 982-990

Brodskii, K. A. (1950). Calanoida of the far eastern seas and polar basin of the USSR. Izv. Akad. Nauk SSSR; 440 pp. (in Russian; English translation 1967)

Coachman, L. K. (1986). Advection and mixing on the BeringChukchi shelves. ISHTAR Progress Report 1986, University of Alaska, Fairbanks

Coachman, L. K., Aagaard, K., Tripp, R. B. (1975). Bering Strait: the regional physical oceanography. Univ. of Washington Press, Seattle

Cody. M. L. (1973). Coexistence, coevolution and convergent evolution in seabird communities. Ecology 54: 31-44 
Cooney, R. T., Coyle, K. O. (1982). Trophic implications of cross-shelf copepod distributions in the Southeastern Bering Sea. Mar Biol. 70: 187-196

Drury, W H., Ramsdell, C., French, J. B., Jr (1981). Ecological studies in the Bering Strait Region. Environmental Assessment of the Alaskan Continental Shelf. Final Reports of Principal Investigators Vol II. NOAA/OMPA, Washington, D.C., p. $175-487$

Furness, R. W., Birkhead, T. R. (1984). Seabird colony distributions suggest competition for food supplies during the breeding season. Nature (Lond.) 311: 655-656

Gaston, A. J., Chapdelaine, G., Noble, D. G. (1983). The growth of thick-billed Murre chicks at colonies in Hudson Strait: inter- and intra-colony variation. Can. J. Zool. 61: 2465-2475

Haury, L. R., McGowan, J. A., Wiebe, P. H. (1978). Patterns and processes in time-space scales of plankton distributions. In: Steele, J. H. (ed.) Spatial pattern in plankton communities. Plenum Press, New York, p. 277-327

Hunt, G. L. (in press). The pelagic distribution of marine birds in an heterogeneous environment. Polar Res.

Hunt, G. L., Burgeson, B., Sanger, G. A. (1981). Feeding ecology of seabirds of the eastern Bering Sea. In: Hood, D. W., Calder, J. A. (eds.) The eastern Bering Sea shelf: oceanography and resources, Vol. II. NOAA/OMPA, Washington, D.C., p. 629-647

Hunt, G. L., Eppley, Z. A., Schneider, D. C. (1986). Reproductive performance of seabirds: the importance of population and colony size. Auk 103: 306-317

Hunt, G. L., Harrison, N. M., Cooney, T. (in press). Foraging of least auklets: the influence of hydrographic structure and prey abundance. Studies avian Biol.

Hunt, G. L., Schneider, D. C. (1987). Scale-dependent processes in the physical and biological environment of marine birds. In: Croxall, J. P. (ed.) Seabirds: feeding ecology and role in marine ecosystems. Cambridge Univ. Press, Cambridge, p. $7-41$

Iverson, R. L., Coachman, L. K., Cooney, R. T., English, T S. Goering, J. J., Hunt, G. L., MacCauley, M. C., McRoy, C. P., Reeburg, W. S., Whitledge, T E. (1979). Ecological significance of fronts in the southeastern Bering Sea. In: Livingston, R. L. (ed.) Ecological processes in coastal and marine ecosystems. Plenum Press. New York, p. $437-465$

Kinder, T H., Schumacher, J. D. (1981). Circulation over the continental shelf of the south-eastern Bering Sea. In: Hood, D. W., Calder, J. A. (eds.) The eastern Bering Sea shelf: oceanography and resources, Vol. 1. NOAA/OMPA, Washington, D.C., p. 53-75

Kinder, T. H., Hunt, G. L., Schneider, D., Schumacher, J. D. (1983). Correlations between seabirds and oceanic fronts

This article was presented by Dr D. C. Schneider, St. John's, Newtoundland, Canada around the Pribilof Islands, Alaska. Estuar. coast. Shelf Sci. 16: 309-319

Meshcheryakova, I. M. (1970). Plankton of the eastern Bering Sea in spring and autumn. Information of the Scientific Research Institute for Fishery and Oceanography in the Pacific Ocean 72, p. 92-108

Miller, C. B. (1988). Neocalanus flemingeri, a new species of Calanidae (Copepoda: Calanoida) from the subarctic Pacific Ocean, with a comparative redescription of Neocalanus plumchrus Maruhawa. Prog. Oceanogr 20: 223-273

Miller, C. B., Clemons, M. J. (1988). Revised life history analysis for large grazing copepods in the subarctic Pacific Ocean. Prog. Oceanogr. 20: 293-313

Motoda, S., Minoda, T. (1974). Plankton of the Bering Sea. In: Hood, D. W., Kelley, E. J. (eds.) Oceanography of the Bering Sea. Proc. International Symposium for Bering Sea Stud. Hakodate, Japan, $31 \mathrm{Jan}-4$ Feb, 1972. Univ. of Alaska, Fairbanks, p. 207-241

Roby, D. D., Brink, K. L. (1986). Breeding biology of Least Auklets on the Pribilof Islands, Alaska. Condor 88: 336-346

Schneider, D., Harrison, N. M., Hunt, G. L. (1987). Variation in the occurrence of marine birds at fronts in the Bering Sea. Estuar. coast. Shelf Sci. 25: 135-141

Schneider, D. C., Hunt, G. L., Harrison, N. M. (1986). Mass and energy transfer to seabirds in the southeastern Bering Sea. Cont. Shelf Res. 5: 241-257

Smith, S. L., Vidal, J. (1984). Spatial and temporal effects of salinity, temperature and chlorophyll on the communities of zooplankton in the southeastern Bering Sea. J. mar. Res. 42: 221-257

Sowls, A. L., Hatch, S. A., Lensink, C. J. (1978). Catalog of Alaskan seabird colonies. Biological Services Program, U.S. Fish and Wildlife Service, Anchorage, Alaska

Springer, A. M., McRoy, C. P., Turco, K. R. (1989). The paradox of pelagic food webs in the northern Bering Sea - II Zooplankton communities. Cont. Shelf Res. 9: 359-386

Springer, A. M., Murphy, E. C., Roseneau, D. G., McRoy, C. P., Cooper, B. P. (1987). Seabird food webs in the northern Bering Sea. Cont. Shelf Res. 7: 895-911

Springer, A. M., Roseneau, D. G. (1985). Copepod-based food webs: auklets and oceanography in the Bering Sea. Mar. Ecol. Prog. Ser. 21: 229-237

Steele, J. H. (1976). Patchiness. In: Cushing, D. H., Walsh, J. J (eds.) Ecology of the sea. Philadelphia, Saunders, $p$ 98-115

Vidal, J., Smith, S. L. (1986). Biomass, growth, and development of populations of herbivorous zooplankton in the southeastern Bering Sea during spring. Deep Sea Res. 33 $525-556$

Manuscript first received: August 5, 1989

Revised version accepted: May 23, 1990 